

Verónica believes that another way to develop the next generation of scientists is through membership in scientific societies. "Professional societies are communities of scientists that share a particular interest in a field such as microbiology or biophysics. These are organisations that can expose you to cutting-edge research and help you connect with mentors, advisors and future colleagues," explains Verónica. "They can also help an aspiring scientist acquire strategies to become an independent scientist in a particular field."

Importantly, these organisations often have a range of ways to engage aspiring scientists and develop their talents in science. There are usually membership levels and programmes that enable students to learn more about a given scientific field and form connections with other members.

Verónica belongs to a number of scientific societies, including the American Society for Cell Biology (ASCB). As a member of ASCB, she has established working relationships with other members who have helped her become a better scientist and take on leadership and mentorship roles in the field.

\section{WHAT IS REWARDING ABOUT}

VERÓNICA'S WORK WITH THE AMERICAN SOCIETY FOR CELL BIOLOGY (ASCB)?

"Being part of ASCB enables me to stay connected with young scientists that are up and coming in the field and they constantly inspire me," says Verónica. "Of course, my work also enables me to stay connected with more seasoned scientists in my field who can provide help and guidance when needed."

As part of her work with ASCB, Verónica is leading its Accomplishing Career Transitions (ACT) programme. The programme enables cell biologists who are starting out their independent careers to customise and individualise their professional development and training through a longitudinal mentoring framework. The ultimate aim is to facilitate their successful transition into the academic STEM workforce. Verónica is keen to emphasise that many of the transferable skills that scientists will need throughout their career are not actually taught through formal training. Thus, Verónica works to design innovative programmes that fill this gap and help young scientists learn these transferrable skills and put them into practice.

\section{WHERE DOES VERÓNICA'S}

PASSION COME FROM AND WHAT MOTIVATES HER?

"I think the energy and drive to move forward and make progress comes from an overlap between my professional and personal missions and values. For example, helping others speaks to the values with which I was raised and is therefore an important part of my identity," says Verónica. "My goal of helping others move forward in their quest of becoming successful scientists aligns perfectly with my personal mission - I am strongly motivated to support the next generation the same way I was helped by my teachers and mentors during my time as a student."

If all that was not enough, Verónica also cofounded The Alliance to Catalyze Change for Equity in STEM Success (ACCESS), which brings together diversity-focused committees from five different scientific societies. When Verónica was the co-chair of the diversityfocused committee of the ASCB (called the Minorities Affairs Committee), she identified a need and looked for ways to collaborate with others to satisfy it.

\section{HOW TO BECOME A CELL BIOLOGIST}

- The American Society for Cell Biology is an exhaustive resource that provides a wealth of information on the international community of biologists: https://www.ascb.org/

- National Geographic has a brilliant resource library, which includes an entire section dedicated to cell biology. We cannot recommend this resource enough:

https://www.nationalgeographic. org/topics/resource-library-cellbiology/?q=\&page=1\&per_page =25

- The average salary can range anywhere between $\$ 81,150$ (microbiologists) and $\$ 105,940$ (biochemists and biophysicists), depending on the level of experience.
Verónica believes that biology, chemistry and physics are good subjects for aspiring cell biologists to take while at school. "Aspiring scientists should also take any other courses they enjoy, especially ones that will inspire them to create and formulate creative solutions to challenges we face as a society," says Verónica. "Problem solving and thinking creatively are transferable skills that can be applied in any field of knowledge."

You will need a degree in a relevant subject for postgraduate study.

https://study.com/articles/Cellular_Biologist_Education_Requirement_and_Career_ Information.html 


\section{BECOME A CELL BIOLOGIST?}

WHAT INTERESTS DID YOU HAVE AS A CHILD?

So many! I loved the arts, including painting and music (I play the clarinet). I also loved reading and writing, as well as playing and exploring!

WHO OR WHAT HAS INSPIRED YOU IN YOUR CAREER?

I had an inspiring science teacher early in school and she made me want to become a scientist. I never doubted I would become one, even when the going got tough - as it often does when you are doing something worthwhile. I have had many mentors along the way who have been a big help, including more experienced scientists, but also peer mentors who have been at a similar stage in their careers.

\section{WHAT CHARACTERISTICS}

HAVE ENABLED YOU TO BE A

SUCCESSFUL SCIENTIST?

I have worked hard through challenges in ways that speak to who I am as a person and my values. I do this despite any fear of failure I might experience. When I make mistakes, I find ways to learn from them and use these lessons to be better in the future.

\section{WHAT HAVE BEEN YOUR PROUDEST CAREER ACHIEVEMENTS SO FAR?} I am proud that I have accomplished my goal of becoming a scientist - looking back and reflecting on my journey makes me super happy. Something that I have come to value even more than my own career trajectory is the accomplishments of my students. I have had the honour of mentoring many undergraduate scientists and have watched each of them create a unique professional trajectory. I am so proud of them!

WHAT AMBITIONS DO YOU STILL HAVE TO ACHIEVE?

My ambitions are to stay relevant and needed in whatever it is that I am doing. I find that my longterm goals tend to change over time, as I adapt and reflect on my life experiences in science and beyond. I find that very exciting - the possibilities are endless in that I can still become whatever it is I want to become. One of my main goals is to stay engaged and creative, building opportunities for myself and others that enable us to connect with science in authentic ways.

\section{VERÓNIGASS TOP TIPS}

01 Do science in a way that speaks to who you are as an individual. Try and create a unique niche that speaks to your passions and values!

02 Do some research on professional societies at the start of your career. Becoming part of the community from the outset will stand you in good stead for the future and undoubtedly introduce you to like-minded people who can inspire you to achieve greater things. Fact: failing fast is the best! Then you can regroup and try again.
Verónica and her undergraduate research team attend the annual meeting of the Association of Southeastern Biologists in 2016 to present their work.

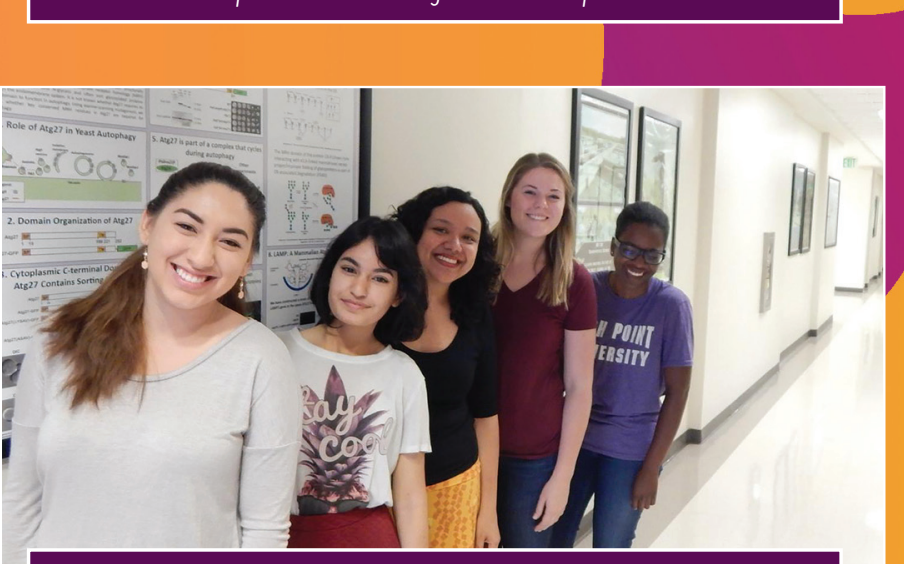

Verónica and her undergraduate research students, excited to begin the 2016 Summer Research Program in the Sciences at High Point University.

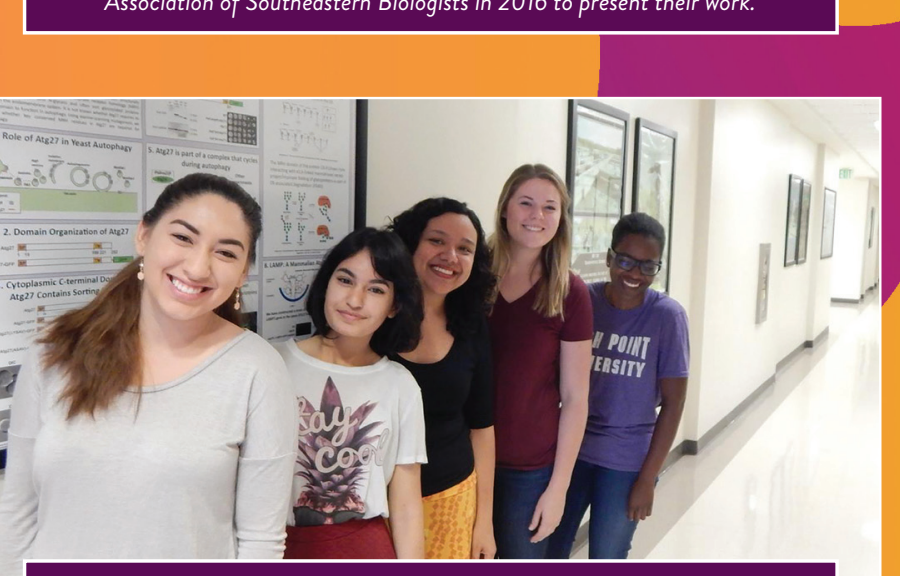

